\title{
Aetiology and pathogenesis of cystic ovarian follicles in dairy cattle: a review
}

\author{
Tom VANHOLDER, Geert OPSOMER*, Aart DE KRUIF \\ Department of Reproduction, Obstetrics and Herd Health, Faculty of Veterinary Medicine, \\ Ghent University, Salisburylaan 133, 9820 Merelbeke, Belgium
}

(Received 23 August 2005; accepted 5 December 2005)

\begin{abstract}
Cystic ovarian follicles (COF) are an important ovarian dysfunction and a major cause of reproductive failure in dairy cattle. Due to the complexity of the disorder and the heterogeneity of the clinical signs, a clear definition is lacking. A follicle becomes cystic when it fails to ovulate and persists on the ovary. Despite an abundance of literature on the subject, the exact pathogenesis of COF is unclear. It is generally accepted that disruption of the hypothalamo-pituitary-gonadal axis, by endogenous and/or exogenous factors, causes cyst formation. Secretion of GnRH/LH from the hypothalamus-pituitary is aberrant, which is attributed to insensitivity of the hypothalamus-pituitary to the positive feedback effect of oestrogens. In addition, several factors can influence GnRH/LH release at the hypothalamo-pituitary level. At the ovarian level, cellular and molecular changes in the growing follicle may contribute to anovulation and cyst formation, but studying follicular changes prior to cyst formation remains extremely difficult. Differences in receptor expression between COF and dominant follicles may be an indication of the pathways involved in cyst formation. The genotypic and phenotypic link of COF with milk yield may be attributed to negative energy balance and the associated metabolic and hormonal adaptations. Altered metabolite and hormone concentrations may influence follicle growth and cyst development, both at the level of the hypothalamus-pituitary and the ovarian level.
\end{abstract}

cystic ovarian follicles / pathogenesis / hypothalamus-pituitary / ovary / negative energy balance

\section{INTRODUCTION}

Cystic ovarian follicles (COF) are an important cause of subfertility in dairy cattle, since they extend the calving interval [1-3]. Prolongation of the calving interval and treatment costs of COF result in economic loss for the dairy farmer. In most of the literature, $\mathrm{COF}$ are referred to as Cystic Ovarian Disease (COD). However, this terminology should be revised since the emphasis on cystic follicles has shifted over time.
In the 1940's, the presence of cystic follicles on the ovaries was mainly associated with nymphomania and a bull-like appearance in cows [4,5], which are clear clinical signs of a state of "disease". Over the past decades, dairy herd management and economics have evolved to a situation in which fertility in the postpartum period is utterly important. During this period, cystic follicles are rather common, and generally occur without obvious clinical signs. Normal ovarian cyclicity is, however, delayed and

\footnotetext{
* Corresponding author: Geert.Opsomer@Ugent.be
} 
these cysts should therefore be regarded as COD, despite the absence of previously "classical" signs of disease in the majority of cases. In addition, after a variable period of time, cysts can become non-steroidogenic and then they no longer interfere with cyclicity $[6,7]$. Consequently, at the time the non-steroidogenic cyst is observed, no other clinical abnormalities are present.

In present-day dairy herd health programmes, "cysts" are often diagnosed in the absence of clear clinical signs. Therefore the term "Cystic Ovarian Disease" no longer seems appropriate and should be replaced by the term "Cystic Ovarian Follicle(s)" which does not necessarily implicate a state of disease. In this review, we will therefore use COF instead of COD. We prefer to use COF instead of "ovarian cysts", because the former term indicates that it is the ovarian follicle(s) and not any other ovarian tissue that becomes cystic.

\section{DEFINITION}

Cystic ovarian follicles develop when one or more follicles fail to ovulate and subsequently do not regress but maintain growth and steroidogenesis. They are defined as follicle-like structures, present on one or both ovaries, with a diameter of at least $2.5 \mathrm{~cm}$ for a minimum of ten days in the absence of luteal tissue [8-11]. It has become clear though that this definition needs to be revised. First, the size limit is rather artificial since follicles might already become cystic at a smaller size, and dominant follicles ovulate on average at a size of 1.6 to $1.9 \mathrm{~cm}$ in dairy cows [12-14]. Moreover, many researchers showed that COF are actually dynamic structures, which can regress and be replaced by new cysts [15-18]. The factors that determine whether a cyst will regress or not, remain unknown $[19,20]$, although changes in mean LH concentration seem to be involved [16]. So the required individual persistency of ten days is questionable. In addition, in practice, veterinarians generally do not have the oppor- tunity to perform a second examination of an animal ten days after the initial diagnosis of COF to fulfill all the terms of the definition. The absence of a corpus luteum is another requirement, which is not always fulfilled [21]. Non-steroidogenic cysts which are hormonally inactive do not influence the normal oestrous cycle, so they can occur together with a corpus luteum. Therefore, recent research articles define COF differently and perhaps more logically [16, 22-24], although a generally accepted definition is still lacking, which can also be attributed to the heterogeneity (type of cyst, time of occurrence, clinical signs) of the cysts.

Based on the current knowledge and recent literature, COF may be defined as follicles with a diameter of at least $2 \mathrm{~cm}$ that are present on one or both ovaries in the absence of any active luteal tissue and that clearly interfere with normal ovarian cyclicity.

Macroscopically, cysts can be subdivided into follicular and luteal cysts, which are considered to be different forms of the same disorder [25]. Luteal cysts are believed to be follicular cysts in later stages [26]. Determination of progesterone concentrations in blood plasma, milk or milk fat can help to make a distinction between the two types. Follicular cysts secrete little or no progesterone while luteal cysts clearly do [26]. However, the threshold values used in the literature differ a lot [27-31], which makes it difficult to set a concentration threshold. In addition, the many intermediate forms with limited or extensive luteinisation do not allow for a clear identification of cyst type. So classification is not easy and is subject to personal interpretation. Ultrasound can be useful in supplying extra information. Follicular cysts have a thin wall $(\leq 3 \mathrm{~mm})$ and the follicular fluid is uniformly anechogenic, while luteal cysts have a thicker wall $(>3 \mathrm{~mm})$, which is visible as an echogenic rim. Also, the latter often have echogenic spots and web-like structures in the follicular fluid $[32,33]$. Luteal cysts should not be confused with hollow corpora lutea, which are not pathological at all [26]. 
Hollow corpora lutea are just young corpora lutea with an antrum [34]. Ultrasound examination of the ovaries is useful in making a distinction between a luteal cyst and a cystic corpus luteum [32, 35].

Follicular cysts initially continue to produce oestrogens in the absence of other follicles $>5 \mathrm{~mm}$ on ultrasound [36]. After a variable period of time oestrogen production may cease. The cyst becomes non-steroidogenic without luteinising, thereby allowing a new follicular wave to emerge and follicles to grow beyond $5 \mathrm{~mm}[6,7]$.

\section{INCIDENCE AND SIGNS}

Cystic ovarian follicles can occur at different times throughout lactation. The incidence varies between 6 and $30 \%[9,11,37-$ 43]. The diagnosis of COF is most often made during the first 60 days post partum $[8,9,38,44]$, mainly because of the close monitoring of cow fertility during this period. The majority of all cysts occur throughout this stage [37, 40, 43]. The selfrecovery percentage of these early cysts is 60-65\% [8, 9, 38, 43]. Despite this high self-recovery rate, the importance in dairy cow fertility is considerable [45]. As reported by Thatcher and Wilcox [46] and more recently by Shrestha et al. [47], early resumption of ovarian cyclicity is beneficial for fertility. By delaying/interfering with ovarian cyclicity, COF increase the time to first insemination and the interval from parturition to conception. In addition, COF decrease the pregnancy rate after first insemination and increase the number of services per conception [47, 48].

A genetic predisposition exists for $\mathrm{COF}$ $[49,50]$, but the heritability is rather low, being 0.07 to 0.12 [51-53]. However, the incidence in Dutch Holstein Friesian herds is actually increasing [51]). Genetic selection to reduce the incidence of COF can be successful, despite the low heritability [54].

The clinical signs that accompany ovarian cysts are variable. Anoestrus is most common, especially during the postpartum period [9]. Irregular oestrus intervals, nymphomania, relaxation of the broad pelvic ligaments and development of masculine physical traits are other signs which may be present, especially later during lactation $[11,55]$.

\section{PATHOGENESIS OF OVARIAN CYSTS}

Ovarian dysfunctions like cysts occur most often during the early postpartum period when there is a transition from the noncyclic condition during pregnancy to the establishment of regular cyclicity. It is generally accepted that cystic follicles develop due to a dysfunction of the hypothalamicpituitary-ovarian axis. This dysfunction has a multifactorial etiology, in which genetic, phenotypic and environmental factors are involved [9, 19, 26]. When discussing the pathogenesis of COF, a distinction may be made between a primary defect in the hypothalamus-pituitary and a primary defect at the level of the ovary in the follicle itself. However, COF formation may result from defects in both ovary/follicle and the hypothalamus/pituitary as well.

\subsection{Hypothalamic-pituitary dysfunction}

The most widely accepted hypothesis explaining the formation of a cyst is that $\mathrm{LH}$ release from the hypothalamus-pituitary is altered: the pre-ovulatory LH-surge is either absent, insufficient in magnitude or occurs at the wrong time during dominant follicle maturation, which leads to cyst formation [8, 16, 18, 41] (Fig. 1). This aberrant LH release does not seem to be caused by a lower GnRH content of the hypothalamus, nor by reduced $\mathrm{GnRH}$ receptor numbers or LH content in the pituitary $[56,57]$.

It is believed that an altered feedback mechanism of oestrogens on the hypothalamus-pituitary can result in an aberrant 


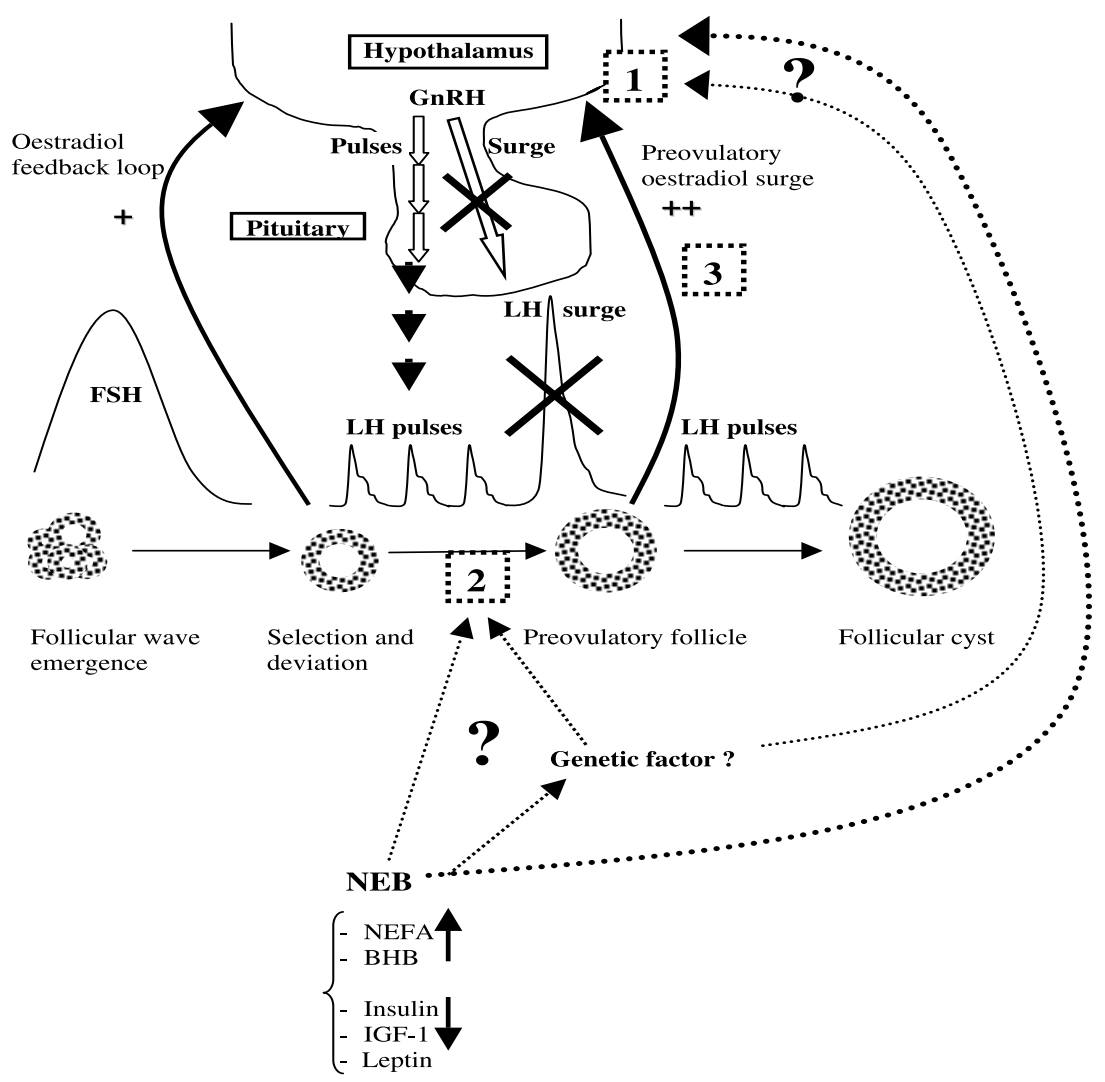

Figure 1. Schematic representation of the pathogenesis of ovarian cysts and the possible pathways involved. An FSH surge stimulates the emergence of a new follicular wave, from which a single dominant follicle is selected at the time of deviation. Through a positive feedback loop oestradiol stimulates GnRH and LH pulsatility, which in turn supports growth and development of the dominant follicle. Upon reaching preovulatory size, follicular steroidogenic activity reaches a peak and produces a preovulatory oestradiol surge. This surge either fails to elicit a GnRH and subsequent LH surge or the GnRH/LH surge is mistimed/delayed. The dominant follicle, therefore, does not ovulate but, due to the ongoing LH pulsatility, continues to grow and becomes a cyst. The disruption of the hypothalamic-pituitary-gonadal axis can be caused by factors affecting the oestradiol feedback mechanism and $\mathrm{GnRH} / \mathrm{LH}$ release at the hypothalamic-pituitary level (1) and/or by an aberrant follicle growth and development with alterations in receptor expression and steroidogenesis (2), leading to an altered oestradiol surge and feedback (3). Hypothalamic-pituitary function and follicular growth/development may be affected by NEB through metabolic/hormonal adaptations. In addition, in the situation of NEB, the expression of genetic hereditary factor(s) associated with COF may be promoted or the functional importance may increase, which in turn may affect follicle growth and hypothalamic-pituitary function.

GnRH/LH release and cyst formation. A GnRH/LH surge occurring prematurely during follicle growth, i.e. when no follicle capable of ovulation is present, can render the hypothalamus unresponsive to the feedback effect of oestradiol which results in the formation of ovarian cysts $[22,58]$. To restore the feedback mechanism, the hypothalamus needs to be exposed to progesterone $[59,60]$. Consequently, a similar state of hypothalamic refractoriness to oestrogens and subsequent cyst formation can be achieved if 
the progesterone rise after a spontaneous ovulation is prevented [61]. This physical state of hypothalamic unresponsiveness to oestrogens seems to be present in the majority of cows with COF, as illustrated by the failure of an exogenous oestradiol treatment to elicit a timely LH surge [62-65]. However, the refractoriness of the hypothalamus-pituitary for oestradiol in cows with COF may be a consequence rather than a cause of the disease. Removal of the cystic ovary by ovariectomy restores the feedback mechanism and the capacity of oestradiol to elicit an LH surge, although the underlying mechanism is not known [66].

An altered feedback mechanism and GnRH/LH release may be attributed to factors interfering at the hypothalamic-pituitary level. Progesterone at suprabasal concentrations blocks the LH-surge, thereby inhibiting ovulation, but increases the $\mathrm{LH}$ pulse frequency $[67,68]$. This results in an anovulatory, persistent follicle with a larger diameter and a longer lifespan than normal, and increased peripheral oestradiol concentrations [68]. These follicular and hormonal changes are very similar to observations made in cows with COF [16]. Recently, Hatler et al. [23] observed that at the time of diagnosis, most cysts are accompanied by suprabasal progesterone concentrations, which play a role in cyst turnover. These observations together with the similarities between persistent follicles, induced by suprabasal progesterone, and naturally occurring cysts, suggest a role for progesterone in the pathogenesis of $\mathrm{COF}$. However, suprabasal progesterone profiles seem to play a limited role in primary COF formation [69]. Factors indirectly reducing GnRH/LH secretion like stress [6, 70-72], intrauterine infections [44, 73] and seasonality [74] are also considered to increase the risk of cyst formation.

In cystic cows, the formation of new cysts is accompanied by increased LH pulse frequencies and amplitudes $[16,57]$. However hypersecretion of $\mathrm{LH}$ does not seem to be involved in cyst formation, but it may play a role in cyst persistence [75]. Data obtained in sheep also dismiss an increased LH secretion as a primary cause of COF [76].

In conclusion, an aberrant LH surge is likely to be the trigger for the development of COF. Abnormal LH release seems to be caused by an altered feedback mechanism of oestrogens on the hypothalamus-pituitary. The malfunctioning of the feedback mechanism can be caused by factors directly interfering at the hypothalamic-pituitary level or by an altered follicle growth and development disrupting the hypothalamic-pituitarygonadal axis, as discussed below.

\subsection{Ovarian/follicular dysfunction}

A primary dysfunction at the level of the follicle may disrupt the hypothalamic-pituitary-ovarian axis and cause the formation of COF (Fig. 1). First of all, alterations in LH receptor expression and content may cause anovulation of the follicle. The LH surge initiates a complex multi-gene, multistep process in which timing is essential, finally leading to ovulation of the pre-ovulatory follicle [77]. According to Kawate et al. [78], FSH and LH receptor numbers in granulosa cells of cysts are decreased when compared to normal follicles, but this is contradicted by data from Odore et al. [79] and Calder et al. [80]. Discrepancies between studies may be explained by differences in methodology such as demonstration of the receptor itself or its mRNA, and the division of cysts into oestrogenactive and oestrogen-inactive. In the same study, Calder et al. [80] also studied developing "young cysts" but no differences in FSH/LH receptor mRNA were observed when compared to dominant follicles. Young cysts were, however, studied in the presence of existing cysts, i.e. when the endocrine environment was already altered, and therefore the pathogenesis may differ from primary developing cysts.

Another receptor of interest is the oestradiol receptor $\beta$ (ER- $\beta$ ). In rodents, the importance of this receptor in follicular growth and development has clearly been demonstrated 
$[81,82]$ and its localisation in follicle cells throughout follicular development has been described in many mammals including cattle [83, 84]. More specifically, in rat ovarian follicles ER- $\beta$ mRNA expression precedes increased expression of mRNA for the LH receptor and specific steroidogenic enzymes [85]. Therefore, alterations in ER- $\beta$ expression may be involved in the development of COF. However, this hypothesis is not supported by data from Calder et al. [80] showing that ER- $\beta$ mRNA expression was not altered in growing young cysts. Odore et al. [79] did, however, find decreased oestrogen receptor concentrations in follicular cysts, but the oestrogen receptor type was not defined.

Besides changes in receptor expression and content, alterations in steroidogenesis by the dominant follicle may also be involved in cystic degeneration. After all, the dominant follicle has to elicit an LH surge at the right time in its development by producing sufficient oestradiol. Oestrogen-active cysts show a higher expression of $3 \beta$-hydroxysteroid dehydrogenase mRNA, a steroidogenic enzyme [80], and cows developing a cyst have increased oestradiol concentrations during the early stages of follicular dominance [86]. However, Calder et al. [80] were unable to observe changes in mRNA expression of steroidogenic enzymes in the follicle wall of young growing cysts. They concluded that alterations of the endocrine system precede, and perhaps cause, the observed follicular alterations in cysts. In the study of Calder et al. [80], young cysts did, however, develop in the presence of existing cysts, i.e. when the endocrine environment was already altered. As a consequence, the mechanism causing these "young cysts" to actually become cysts may differ from the mechanism(s) involved in primary cyst formation.

Apart from changes in mRNA expression for certain receptors and steroidogenic enzymes, cell proliferation and apoptosis in the granulosa and theca interna cell layers also seem to be altered in cystic follicles.
Early cystic follicles show an increase in apoptosis while cell proliferation is decreased [87, 88]. Although it is hard to establish a cause-effect relationship, alterations like these may disrupt normal follicle growth and steroidogenesis leading to cystic degeneration.

Recently, Imai et al. [89] suggested that matrix metalloproteinases (MMP) could be involved in the formation of cysts: higher proMMP-2 and-9 levels were present in the follicular fluid of cysts than in the follicular fluid of normal dominant follicles. MMP play a role in follicle wall remodelling and rupture at the time of ovulation [77, 90], but hereto the inactive proMMP form needs to be transformed to the active MMP form. This activation is triggered by the LH-surge [77]. Since an aberrant LH-surge causes COF formation, the higher proMMP-2 and -9 levels in the follicular fluid of COF are most likely an indication of the lack of an LH-surge rather than a cause of COF formation.

\subsection{Predisposing factors for $\mathrm{COF}$}

As mentioned before, COF are mainly observed in high yielding dairy cows during the first months post partum and milk yield is generally considered a risk factor $[40,51$, 88, 86, 91-93], although not all authors agree $[37,94]$. Moreover, besides the fact that a genetic predisposition for COF exists (see above), a genetic correlation between cysts and milk production traits has been established, indicating that an ongoing selection for production parameters will increase the incidence of COF [51]. What the genetic factor(s) are and how they promote the formation of cysts is not known. However, the fact that cows do not develop a cyst during every lactation and during every ovarian cycle indicates that gene expression may be promoted by, or gains functional importance under, certain stressors, for example high milk yield and the associated negative energy balance (NEB) during the early postpartum period. At this 
time, energy requirements to sustain milk yield are higher than energy intake thus causing a NEB. This NEB is accompanied by several hormonal and metabolic adaptations, affecting ovarian function [95]. Energy balance may be a more accurate parameter than milk yield to further elucidate the association between $\mathrm{COF}$ and production traits. Some animals can compensate for higher milk production through greater dry matter intake reducing the effect of milk yield on energy balance [92]. This could explain why not all authors [37, 94] observed a correlation between ovarian cysts and milk yield. However, when focussing on energy balance and the occurrence of COF, the results still remain inconclusive. While Zulu et al. [24], Refsdal [43] and Sovani et al. [96] observed a deeper NEB and increased mobilization of body reserves in cows developing cysts, Beam [86] noticed that the nadir of the NEB occurred later post partum in cystic cows than in ovulatory cows. Moreover, cystic cows even mobilized less body reserves and derived a smaller percentage of their milk yield from body weight loss [86]. Hooijer et al. [97] were unable to find a more severe NEB, evaluated by the fat/protein ratio in milk, in cows with COF compared to ovulatory cows. However in an earlier study, Heuer et al. [91] observed that a high fat/protein ratio, and, therefore, a more severe NEB, increased the risk of cyst occurrence. Data in sheep also suggest that an increased mobilisation of body reserves, indicative for a deeper NEB, is linked with the occurrence of cystic follicles [76]. Although a concensus is lacking, we conclude from the literature that a link seems to exist between $\mathrm{COF}$ and the magnitude and/or duration of the NEB.

The possible underlying mechanism(s) is(are) also still unclear, but NEB may affect COF formation at both the level of the hypthalamus/pituitary and the ovary/follicle through associated hormonal and metabolic changes [98, 99] (Fig. 1). During NEB, peripheral plasma concentrations of IGF-1, insulin, glucose [95] and leptin [100, 101] are reduced, while concentrations of metab- olites such as non-esterified fatty acids (NEFA) [102] and $\beta$-hydroxybutyrate (BHB) are increased [103]. The IGF-system plays an important role in follicle growth and development [104]. Besides a direct effect, IGF-1 together with insulin indirectly stimulates follicular development through upregulation of the LH-receptor on granulosa cells [105]. Therefore, low systemic IGF-1 concentrations early post partum could contribute to anovulation and subsequent development of cystic follicles as shown by Zulu et al. [24]. However, data from Beam [86] do not confirm this hypothesis. Also insulin itself is known to be a potent stimulator of follicle cell steroidogenesis and proliferation in vitro $[106,107]$ and in vivo [108-110]. Consequently, reduced circulating insulin concentrations early post partum may play a role in ovarian dysfunction i.e. cyst formation, as we have recently demonstrated [69]. Besides low insulin concentrations, a general state of peripheral insulin resistance is present as well in high yielding dairy cows early post partum [111, 112]. Insulin resistance is regarded as an important factor in the pathogenesis of the Polycystic Ovary Syndrome (PCOS) in women [113-115] and COF have often been compared to this syndrome, justified or not. However, insulin insufficiency rather than insulin resistance has been observed in COF cows [116], indicating an altered interaction between glucose and insulin at the pancreatic level. In addition, in ewes it was not possible to induce cyst formation through the establishment of a state of insulin resistance [76]. Conclusively, IGF-1 and insulin are important stimulators of follicle growth and based on the limited number of publications on the subject, low concentrations of one or both hormones may contribute to the formation of COF (Fig. 2). Further research should confirm whether or not this hypothesis is valid.

Leptin is a recently "new" hormone, produced by adipocytes, and is regarded as the ultimate factor linking metabolic status to reproduction [117]. Depending on the metabolic state of the animal it either has a 


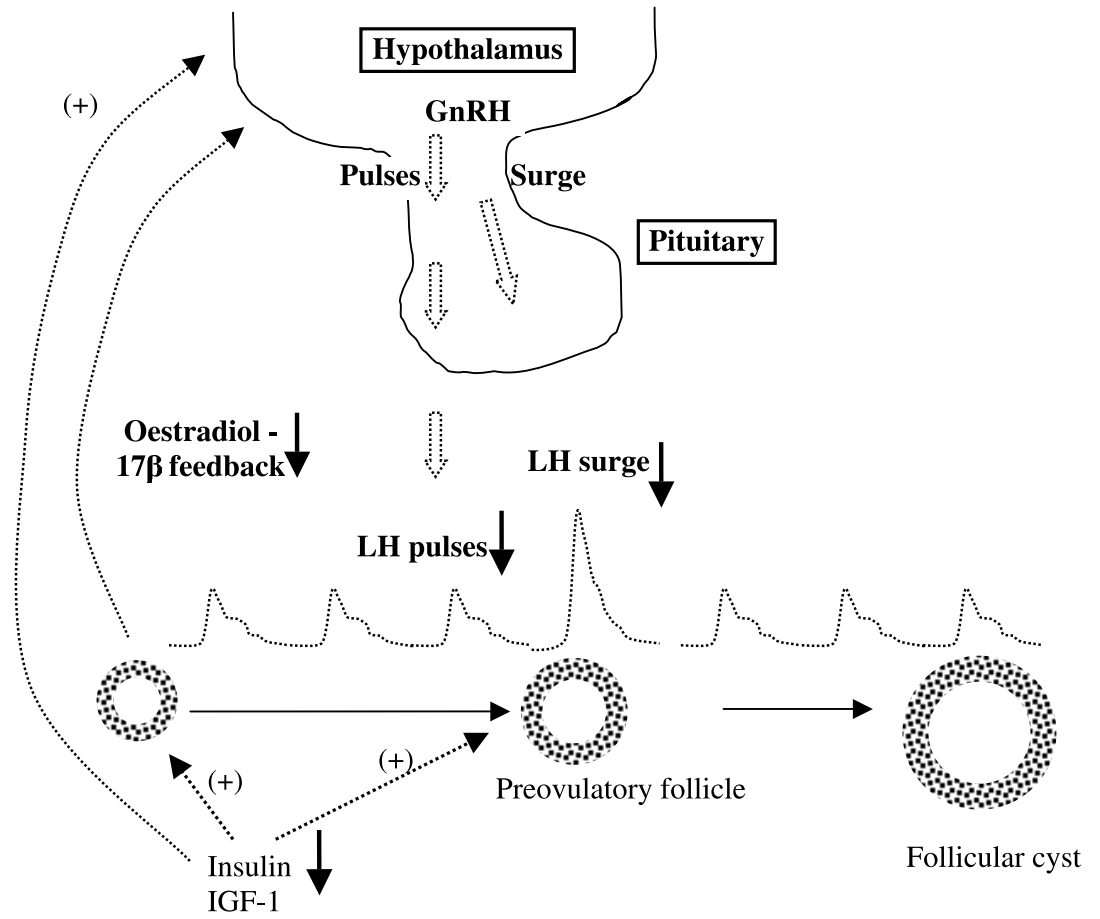

Figure 2. Schematic model of how low insulin and/or IGF-1 concentrations may cause cyst formation. Low insulin/IGF-1 concentrations insufficiently $(+)$ stimulate follicle cell proliferation and oestradiol-17 $\beta$ production. The reduced oestradiol-17 $\beta$ feedback, together with the low insulin/IGF-1 concentrations result in a reduced gonadotropin release. Dominant follicle growth is retarded and the altered follicular growth pattern and oestradiol-17 $\beta$ production disrupt the hypothalamo-pituitary-gonadal axis. This finally results in an aberrant LH-surge and the subsequent development of a cystic follicle.

stimulatory effect or none at all on hypothalamic-pituitary function in cattle [118120]. In the postpartum dairy cow, a clear relationship between leptin profiles and first postpartum ovulation is lacking [101], although a minimum permissive level of leptin seems required to induce the first postpartum LH surge [101, 121]. Therefore, leptin may play a role in early post partum cyst development.

According to Zulu et al. [24] and Huszenicza et al. [122] cows developing cysts have higher serum NEFA concentrations during the first week(s) post partum than ovulatory cows, although Beam [86] was unable to observe this. Interestingly, in rats, elevated NEFA concentrations for
$48 \mathrm{~h}$ can decrease insulin secretion by the $\beta$-cells of the pancreatic islets in response to a glucose challenge [123]. Moreover, NEFA are cytotoxic for several cell types [124-127], including bovine granulosa and theca cells [128, 129]. So (prolonged) exposure to high NEFA concentrations during periods of NEB may hamper follicle growth and development, disrupting the complex endocrine system and promoting the formation of ovarian cysts.

Although elevated serum ketone concentrations increase the risk of delayed cyclicity $[122,130,131]$ and cyst occurrence $[132$, 133] post partum, they do not exert any negative effects on bovine follicle cells in vitro [134]. Consequently, ketone concentrations 
in the postpartum dairy cow seem to be an indicator of the severity of the NEB, but not a mediator of the negative effects of the NEB on reproduction at the ovarian level.

\section{CONCLUSION}

Cystic ovarian follicles are one of the most frequent and important ovarian disorders in modern high yielding dairy cows that have been the subject of much research in recent decades. However, many aspects of the disease, and especially pathogenesis, remain unclear and inconclusive, as for example, illustrated by the lack of a clear definition. In particular, the endocrine and follicular changes that precede spontaneous cyst formation are still unknown, mainly due to the heterogeneity and unpredictability of the disease. Studies aimed at elucidating the pathogenesis, have tried to do so by induction of cysts. This, however, may not mimic naturally-occurring cysts. Nevertheless, such experiments have enhanced our knowledge about the endocrine and follicular changes that occur after cyst formation. Development of an accurate model mimicking the in vivo situation or identification of criteria to allow classification of a follicle as a future cyst before it actually becomes cystic, would be very valuable in studying the cellular and molecular changes that precede ovarian cyst formation.

Due to the genetic correlation with production traits and the high incidence of ovarian cysts during the period of NEB early post partum, future research should also focus on the effect of NEB-associated metabolic/hormonal changes and energy utilisation on follicular development and steroidogenesis. Understanding how NEB affects cyst formation will help to optimise management and feeding practices in preventing the occurrence of ovarian cysts/ COF.

Further research on cellular changes in follicular cysts may elucidate which genes show an altered expression pattern com- pared to normal dominant follicles and could therefore be involved in the primary development. Genetic knock-out models as well may help to determine which genes play a role in cyst formation. The identification of these genes would be an initial step in the process of identifying the hereditary factor(s), making it possible to genetically screen bulls and cows for COF prior to their use in artificial insemination programmes.

\section{ACKNOWLEDGEMENTS}

T. Vanholder is supported by a fellowship from the Special Research Fund, Ghent University, grant No. 011D8501.

\section{REFERENCES}

[1] Lee LA, Ferguson JD, Galligan DJ. The use of survival analysis to quantitate days open, advantages and implications. Acta Vet Scand 1988, 84: 433-435.

[2] Borsberry S, Dobson H. Periparturient diseases and their effect on reproductive performance in five dairy herds. Vet Rec 1989, 124: $217-219$.

[3] Fourichon C, Seegers H, Malher X. Effect of disease on reproduction in the dairy cow: a meta-analysis. Theriogenology 2000, 53: 1729-1759.

[4] Cassida LE, McShan WH, Meyer RK. Effects of an unfractionated pituitary extract upon cystic ovaries and nymphomania in cows. $\mathbf{J}$ Anim Sci 1944, 3: 273.

[5] Garm O. A study of bovine nymphomania. Acta Endocrinol 1949, Suppl 3: 1.

[6] Dobson H, Ribadu AY, Noble KM, Tebble JE, Ward WR. Ultrasonography and hormone profiles of adrenocorticotrophic hormone (ACTH)-induced persistent ovarian follicles (cysts) in cattle. J Reprod Fertil 2000, 120: 405-410.

[7] Noble KM, Tebble JE, Harvey D, Dobson H. Ultrasonography and hormone profiles of persistent ovarian follicles (cysts) induced with low doses of progesterone in cattle. $\mathrm{J}$ Reprod Fertil 2000, 120: 361-366. 
8] Day N. The diagnosis, differentiation, and pathogenesis of cystic ovarian disease. Vet Med 1991, 86: 753-760.

9] Kesler DJ, Garverick HA. Ovarian cysts in dairy cattle: a review. J Anim Sci 1982, 55: 1147-1159.

[10] Woolums AR, Peter AT. Cystic Ovarian Condition in Cattle. Part I Folliculogenesis and Ovulation. Compend Contin Educ Pract Vet (Food Animal) 1994, 16: 935-942.

[11] Youngquist RS. Cystic follicular degeneration in the cow. In: Morrow D (Ed), Current therapy in Theriogenology, 2nd ed, WB Saunders Co, Philadelphia, 1986, p 243-246.

[12] Bleach ECL, Glencross RG, Knight PG. Association between ovarian follicle development and pregnancy rates in dairy cows undergoing spontaneous oestrous cycles. Reproduction 2004, 127: 621-629.

[13] Lopez H, Satter LD, Wiltbank MC. Relationship between level of milk production and estrous behavior of lactating dairy cows. Anim Reprod Sci 2004, 81: 209-223.

[14] Savio JD, Boland MP, Roche JF. Development of dominant follicles and length of ovarian cycles in post-partum dairy cows. J Reprod Fertil 1990, 88: 581-591.

[15] Cook DL, Smith CA, Parfet JR, Youngquist RS, Brown EM, Garverick HA. Fate and turnover rate of ovarian follicular cysts in dairy cows. J Reprod Fertil 1990, 89: 155-166.

[16] Hamilton SA, Garverick HA, Keisler DH, Xu ZZ, Loos K, Youngquist RS, Salfen BE. Characterization of ovarian follicular cysts and associated endocrine profiles in dairy cows. Biol Reprod 1995, 53: 890-898.

[17] Kesler DJ, Garverick HA, Caudle AB, Elmore RG, Youngquist RS, Bierschwal CJ. Reproductive hormone and ovarian changes in cows with ovarian cysts. J Dairy Sci 1980, 63: $166-170$

[18] Yoshioka K, Iwamura S, Kamomae H. Ultrasonic observations on the turnover of ovarian follicular cysts and associated changes of plasma LH, FSH, progesterone and oestradiol-17ß in cows. Res Vet Sci 1996, 61:240244.

[19] Peter AT. An update on cystic ovarian degeneration in cattle. Reprod Domest Anim 2004, 39: 1-7.

[20] Wiltbank MC, Gümen A, Sartori R. Physiological classification of anovulatory condi- tions in cattle. Theriogenology 2002, 57: $21-52$

[21] Al-Dahash SYA, David JSE. Anatomical features of cystic ovaries found during an abattoir survey. Vet Rec 1977, 101: 320-324.

[22] Gümen A, Sartori R, Costa FMJ, Wiltbank MC. A GnRH/LH surge without subsequent progesterone exposure can induce development of follicular cysts. J Dairy Sci 2002, 85: 43-50.

[23] Hatler TB, Hayes SH, Laranja da Fonseca LF, Silvia WJ. Relationship between endogenous progesterone and follicular dynamics in lactating dairy cows with ovarian follicular cysts. Biol Reprod 2003, 69: 218-223.

[24] Zulu VC, Sawamukai Y, Nakada K, Kida K, Moriyoshi M. Relationship among insulinlike growth factor-I, blood metabolites and post partum ovarian function in dairy cows. $\mathbf{J}$ Vet Med Sci 2002, 64: 879-885.

[25] Opsomer G, Coryn M, Mijten P, Kruif A. Post-partum anoestrus bij melkvee. Vlaams Diergeneesk Tijdsch 1997, 66: 61-67.

[26] Garverick HA. Ovarian follicular cysts in dairy cows. J Dairy Sci 1997, 80: 995-1004.

[27] Booth JM. The milk progesterone test as an aid to the diagnosis of cystic ovaries in dairy cows. Vet Rec 1988, 123: 437-439.

[28] Dinsmore RP, White ME, Guard CL, Jasko DJ, Perdrizet JA, Powers PM, Smith MC. Effect of gonadotropin-releasing hormone on clinical response and fertility in cows with cystic ovaries, as related to milk progesterone concentration and days after parturition. J Am Vet Med Assoc 1989, 195: 327-330.

[29] Douthwaite R, Dobson H. Comparison of different methods of diagnosis of cystic ovarian disease in cattle and an assessment of its treatment with a progesterone-releasing intravaginal device. Vet Rec 2000, 147: 355-359.

[30] Leslie KE, Bosu WTK. Plasma progesterone concentrations in dairy cows with cystic ovaries and clinical response following fenprostalene. Can Vet J 1983, 24: 352-356.

[31] Nakao T, Sugihashi A, Saga N, Tsunoda N, Kawata K. Use of milk progesterone enzyme immunoassay for differential diagnosis of follicular cyst, luteal cyst, and cystic corpus luteum in cows. Am J Vet Res 1983, 44: 888890.

[32] Edmondson AJ, Fissore RA, Pashen RL, Bondurant $\mathrm{R}$. The use of ultrasonography for the study of the bovine reproductive tract 1 . 
Normal and pathological ovarian structures. Anim Reprod Sci 1986, 12: 157-165.

[33] Jeffcoate IA, Ayliffe TR. An ultrasonographic study of bovine cystic ovarian disease and its treatment. Vet Rec 1995, 136: 406410 .

[34] Max A, Jurka P, Witowski M, Boryczko Z, Bostedt H. Kritischer Vergleich zwischen klinisch und ultrasonografisch erfassten Ovarbefunden im Interoestrus des Rindes. Tier Prax 1997, 25: 207-211.

[35] Hanzen C, Pieterse M, Scenczi O, Drost M. Relative accuracy of the identification of ovarian structures in the cow by ultrasonography and palpation per rectum. Vet J 2000, 159: $161-170$.

[36] Scott SJ, Dobson H. Postmortem comparison of ultrasonography, endocrine measurements and histology of large abnormal follicles in cows. Vet Rec 1997, 140: 654-656.

[37] Bartlett PC, Ngategize PK, Kaneene JB, Kirk $\mathrm{JH}$, Anderson SM, Mather EC. Cystic follicular disease in Michigan Holstein-Friesian cattle: incidence, descriptive epidemiology and economic impact. Prev Vet Med 1986, 4: 15-33.

[38] Day N. The treatment and prevention of cystic ovarian disease. Vet Med 1991, 86: 761-766.

[39] Erb HN, White ME. Incidence rates of cystic follicles in Holstein cows according to 15-day and 30-day intervals. Cornell Vet 1981, 71: 326-331.

[40] Laporte HM, Hogeveen H, Schukken YH, Noordhuizen JPTM. Cystic ovarian disease in Dutch dairy cattle I. Incidence, risk factors and consequences. Livest Prod Sci 1994, 38 : 191-197.

[41] Lopez-Diaz MC, Bosu WTK. A review of cystic ovarian degeneration in ruminants. Theriogenology 1992, 37: 1163-1183.

[42] Opsomer G, Coryn M, Deluyker H, de Kruif A. An analysis of ovarian dysfunction in high yielding dairy cows after calving based on progesterone profiles. Reprod Domest Anim 1998, 33: 193-204.

[43] Refsdal AO. Ovariecyster hos melkekyr. Norsk Veterinærtidsskrift 1982, 94: 789-796.

[44] Bosu WTK, Peter AT. Evidence for a role of intrauterine infections in the pathogenesis of cystic ovaries in postpartum dairy cows. Theriogenology 1987, 28: 725-736.
[45] López-Gatius F, Santolaria P, Yániz J, Fenech M, López-Béjar M. Risk factors for postpartum ovarian cysts and their spontaneous recovery or persistence in lactating dairy cows. Theriogenology 2002, 58: 1623-1632.

[46] Thatcher WW, Wilcox CJ. Post partum estrus as an indicator of reproductive status in the dairy cow. J Dairy Sci 1973, 56: 608-610.

[47] Shrestha HK, Nakao T, Higaki T, Suzuki T, Akita M. Effects of abnormal ovarian cycles during pre-service period postpartum on subsequent reproductive performance of highproducing Holstein cows. Theriogenology 2004, 61: 1559-1571.

[48] Hooijer GA, van Oijen MAAJ, Frankena K, Valks MMH. Fertility parameters of dairy cows with cystic ovarian disease after treatment with gonadotrophin-releasing hormone. Vet Rec 2001, 149: 383-386.

[49] Cole WJ, Bierschwal CJ, Youngquist RS, Braun WF. Cystic ovarian disease in a herd of Holstein cows: a hereditary correlation. Theriogenology 1986, 25: 813-820.

[50] Kirk JH, Huffman EM, Lane M. Bovine cystic ovarian disease: hereditary relationships and case study. J Am Vet Med Assoc 1982, 181: 474-476.

[51] Hooijer GA, Lubbers RBF, Ducro BJ, van Arendonk JAM, Kaal-Lansbergen LMTE, van der Lende T. Genetic parameters for cystic ovarian disease in Dutch black and white dairy cattle. J Dairy Sci 2001, 84: 286291.

[52] Lin HK, Oltenacu PA, Van Vleck LD, Erb HN, Smith RD. Heritabilities of and genetic correlations among six health problems in Holstein cows. J Dairy Sci 1989, 72: 180186.

[53] Uribe HA, Kennedy BW, Martin SW, Kelton DF. Genetic parameters for common health disorders of Holstein cows. J Dairy Sci 1995, 78: $421-430$.

[54] Anonymous. Swedish Agriculture. Statistics Yearbook for 1976 to 1977, 1978, p 114.

[55] Roberts SJ. Infertility in the cow. In: Veterinary Obstetrics and Genital Diseases, Theriogenology, 3rd ed, Woodstock, Vermont, p 421-433.

[56] Brown JL, Schoenemann HM, Reeves JJ. Effect of treatment on LH and FSH receptors in chronic cystic-ovarian diseased dairy cows. J Anim Sci 1986, 62: 1063-1071. 
[57] Cook DL, Parfet JR, Smith CA, Moss GE, Youngquist RS, Garverick HA. Secretory patterns of LH and FSH during development and hypothalamic and hypophysial characteristics following development of steroidinduced ovarian follicular cysts in dairy cattle. J Reprod Fertil 1991, 91: 19-28.

[58] Gümen A, Wiltbank MC. An alteration in the hypothalamic action of estradiol due to lack of progesterone exposure can cause follicular cysts in cattle. Biol Reprod 2002, 66: 16891695.

[59] Ozturk M, Smith RF, Dobson H. Effect of prolonged exposure to oestradiol on subsequent LH secretion in ewes. J Reprod Fertil 1998, 114: 1-9.

[60] Gümen A, Wiltbank MC. Length of progesterone exposure needed to resolve large follicle anovular condition in dairy cows. Theriogenology 2005, 63: 202-218.

[61] Gümen A, Wiltbank MC. Follicular cysts occur after a normal estradiol-induced GnRH/ LH surge if the corpus hemorrhagicum is removed. Reproduction 2005, 129: 737-745.

[62] Dobson H, Nanda AS. Reliability of cyst diagnosis and effect of energy status on $\mathrm{LH}$ released by estradiol or GnRH in cows with ovarian cysts. Theriogenology 1992, 37: 465-472.

[63] Refsal KR, Jarrin-Maldonado JH, Nachreiner RF. Endocrine profiles in cows with ovarian cysts experimentally induced by treatment with exogenous estradiol or adrenocorticotropic hormone. Theriogenology 1987, 28: 871-889.

[64] Refsal KR, Jarrin-Maldonado JH, Nachreiner RF. Basal and estradiol-induced release of gonadotropins in dairy cows with naturally occurring ovarian cysts. Theriogenology 1988, 30: 679-693.

[65] Zaied AA, Garverick HA, Kesler DJ, Bierschwal CJ, Elmore RG, Youngquist RS. Luteinizing hormone response to estradiol benzoate in cows postpartum and cows with ovarian cysts. Theriogenology 1981, 16: 349-358.

[66] De Silva M, Reeves JJ. Hypothalamic-pituitary function in chronically cystic and regularly cycling dairy cows. Biol Reprod 1988, 38: 264-269.

[67] Duchens M, Forsberg M, Edqvist L-E, Gustafsson $\mathrm{H}$, Rodríguez-Martínez H. Effect of induced suprabasal progesterone levels around estrus on plasma concentrations of progesterone, estradiol-17 $\beta$ and LH in heifers. Theriogenology 1994, 42: 1159-1169.

[68] Stock AE, Fortune JE. Ovarian follicular dominance in cattle: relationship between prolonged growth of the ovulatory follicle and endocrine parameters. Endocrinology 1993, 132: 1108-1114.

[69] Vanholder T, Leroy JLMR, Dewulf J, Duchateau L, Coryn M, de Kruif A. Hormonal and metabolic profiles of high-yielding dairy cows prior to ovarian cyst formation or first ovulation post partum. Reprod Domest Anim 2005, 40: 460-469.

[70] Ribadu AY, Nakada K, Moriyoshi M, Zhang WC, Tanaka Y, Nakao T. The role of LH pulse frequency in ACTH-induced ovarian follicular cysts in heifers. Anim Reprod Sci 2000, 64: 21-31.

[71] Stoebel DP, Moberg GP. Repeated acute stress during the follicular phase and luteinizing hormone surge of dairy heifers. J Dairy Sci 1982, 65: 92-96.

[72] Stoebel DP, Moberg GP. Effect of adrenocorticotropin and cortisol on luteinizing hormone surge and estrous behavior of cows. J Dairy Sci 1982, 65: 1016-1024.

[73] Peter AT, Bosu WTK, Dedecker RJ. Suppression of preovulatory luteinizing hormone surges in heifers after intrauterine infusions of Escherichia coli endotoxin. Am J Vet Res 1989, 50: 368-373.

[74] Emanuelson U, Bendixen PH. Occurrence of cystic ovaries in dairy cows in Sweden. Prev Vet Med 1991, 10: 261-271.

[75] Hampton JH, Salfen BE, Bader JF, Keisler DH, Garverick HA. Ovarian follicular responses to high doses of pulsatile luteinizing hormone in lactating dairy cattle. J Dairy Sci 2003, 86: 1963-1969.

[76] Christman SA, Bailey MT, Head WA, Wheaton JE. Induction of ovarian cystic follicles in sheep. Domest Anim Endocrin 2000, 19: 133-146.

[77] Robker RL, Russell DL, Yoshioka S, Chidanada Sharma S, Lydon JP, O'Malley BW, Espey LL, Richards JS. Ovulation: a multi-gene, multi-step process. Steroids 2000, 65: 559-570.

[78] Kawate N, Inaba T, Mori J. A quantitative comparison in the bovine of steroids and gonadotropin receptors in normally developing follicles and in follicular and luteinized cysts. Anim Reprod Sci 1990, 23: 273-281. 
[79] Odore R, Re G, Badino P, Donn A, vigo D, Biolatti B, Girardi C. Modifications of receptor concentrations for adrenaline, steroid hormones, prostaglandin $\mathrm{F}_{2 \alpha}$ and gonadotropins in hypophysis and ovary of dairy cows with ovarian cysts. Pharmacol Res 1999, 39: 297304.

[80] Calder MD, Manikkam M, Salfen BE, Youngquist RS, Lubahn DB, Lamberson WR, Garverick HA. Dominant bovine ovarian follicular cysts express increased levels of messenger RNAs for luteinizing hormone receptor and 3ß-hydroxysteroid dehydrogenase $\Delta^{4}, \Delta^{5}$ isomerase compared to normal dominant follicles. Biol Reprod 2001, 65: 471-476.

[81] Robker RL, Richards JS. Hormone-induced proliferation and differentiation of granulosa cells: a coordinated balance of the cell cycle regulators cyclin D2 and p2 $7^{\mathrm{kip} 1}$. Mol Endocrinol 1998, 12: 924-940.

[82] Wang XN, Greenwald GS. Synergistic effects of steroids with FSH on folliculogenesis, steroidogenesis and FSH- and hCGreceptors in hypophysectomized mice. J Reprod Fertil 1993, 99: 403-413.

[83] Byers M, Kuiper GGJM, Gustafsson J-Å, Park-Sarge O-K. Estrogen receptor- $\beta$ mRNA expression in rat ovary: down-regulation by gonadotropins. Mol Endocrinol 1997, 11: 172-182.

[84] Rosenfeld CS, Yuan X, Manikkam M, Calder MD, Garverick HA. Cloning, sequencing, and localization of bovine estrogen receptor- $\beta$ within the ovarian follicle. Biol Reprod 1999, 60: 691-697.

[85] Bao B, Kumar N, Karp RM, Garverick HA, Sundaram K. Estrogen receptor- $\beta$ expression in relation to the expression of luteinizing hormone receptor and cytochrome P450 enzymes in rat ovarian follicles. Biol Reprod 2000, 63: 1747-1755.

[86] Beam SW. Follicular development in postpartum cattle: effects of energy balance and dietary lipid. $\mathrm{PhD}$ dissertation, Cornell University, 1995, p 124-136.

[87] Isobe N, Yoshimura Y. Localization of apoptotic cells in the cystic ovarian follicles of cows: a DNA-end labelling histochemical study. Theriogenology 2000, 53: 897-904.

[88] Isobe N, Yoshimura Y. Immunocytochemical study of cell proliferation in the cystic ovarian follicles in cow. Theriogenology 2000, 54: 1159-1169.
[89] Imai K, Khandoker MAMY, Yonai M, Takahashi T, Sato T, Ito A, Hasegawa Y, Hashizume K. Matrix metalloproteinases-2 and -9 activities in bovine follicular fluid of different-sized follicles: relationship to intrafollicular inhibin and steroid concentrations. Domest Anim Endocrin 2003, 24: 171-183.

[90] Smith MF, McIntush EW, Ricke WA, Kojima FN, Smith GW. Regulation of ovarian extracellular matrix remodelling by metalloproteinases and their tissue inhibitors: effects on follicular development, ovulation and luteal function. J Reprod Fertil 1999, Suppl 54: 367-381.

[91] Heuer C, Schukken YH, Dobbelaar P. Postpartum body condition score and results from the first test day milk yield as predictors of disease, fertility, yield, and culling in commercial dairy herds. J Dairy Sci 1999, 82: 295-304.

[92] Lucy MC. Reproductive loss in high-producing dairy cattle: where will it end? J Dairy Sci 2001, 84: 1277-1293.

[93] Rajala PJ, Gröhn YT. Disease occurrence and risk factor analysis in Finnish Ayrshire cows. Acta Vet Scan 1998, 39: 1-13.

[94] Nanda AS, Ward WR, Dobson H. The relationship between milk yield and cystic ovarian disease in cattle. Br Vet J 1989, 145: $39-45$.

[95] Beam SW, Butler WR. Effects of energy balance on follicular development and first ovulation in postpartum dairy cows. J Reprod Fertil 1999, Suppl 54: 411-424.

[96] Sovani S, Heuer C, Straalen WM van, Noordhuizen JPTM. Disease in high producing dairy cows following post parturient negative energy balance. Soc Vet Epid Prev Med, Annual Conference, Edinburgh, 2000.

[97] Hooijer GA, van Oijen MAAJ, Frankena K, Noordhuizen JPTM. Milk production parameters in early lactation: potential risk factors of cystic ovarian disease in Dutch dairy cows. Livest Prod Sci 2003, 81: 25-33.

[98] Diskin MG, Mackey DR, Roche JF, Sreenan JM. Effects of nutrition and metabolic status on circulating hormones and ovarian follicle development in cattle. Anim Reprod Sci 2003, 78: 345-370.

[99] Lucy MC. Mechanisms linking nutrition and reproduction in postpartum cows. Reproduction 2003, Suppl 61: 415-427. 
[100] Block SS, Butler WR, Ehrhardt RA, Bell AW, Van Amburgh ME, Boisclair YR. Decreased concentration of plasma leptin in periparturient dairy cows is caused by negative energy balance. J Endocrinol 2001, 171: 339-348.

[101]Liefers SC, Veerkamp RF, te Pas MFW, Delavaud $\mathrm{C}$, Chilliard Y, van der Lende T. Leptin concentrations in relation to energy balance, milk yield, intake, live weight, and estrus in dairy cows. J Dairy Sci 2003, 86: 799-807.

[102] Rukkwamsuk T, Geelen MJH, Kruip TAM, Wensing T. Interrelation of fatty acid composition in adipose tissue, serum, and liver of dairy cows during the development of fatty liver postpartum. J Dairy Sci 2000, 83: $52-59$.

[103] Leroy JLMR, Vanholder T, Delanghe JR, Opsomer G, Van Soom A, Bols PEJ, De Wulf J, de Kruif A. Metabolic changes in follicular fluid of the dominant follicle in high-yielding dairy cows early post partum. Theriogenology 2004, 62: 1131-1143.

[104] Spicer LJ, Echternkamp SE. The ovarian insulin and insulin-like growth factor system with an emphasis on domestic animals. Domest Anim Endocrin 1995, 12: 223-245.

[105] Davoren JB, Kasson BG, Li CH, Hsueh AJW. Specific insulin-like growth factor (IGF) I-and II-binding sites on rat granulosa cells: relation to IGF action. Endocrinology 1986, 119: 2155-2162.

[106] Gutierrez-Aguilar CG. The effect of nutrition and metabolic hormones on follicular development in cattle. $\mathrm{PhD}$ dissertation, University of Edinburgh, 1997, p 146-166.

[107] Price CA, Silva JM. Intracellular regulation of $\mathrm{P} 450$ aromatase by FSH and insulin in bovine granulosa cells. J Reprod Fertil 1999. Abstract Series 23: 5

[108] Matamaros IA, Cox NM, Moore AB. Exogenous insulin and additional energy affect follicular distribution, follicular steroid concentrations, and granulosa cell human chorionic gonadotropin binding in swine. Biol Reprod 1990, 43: 1-7.

[109] Armstrong DG, Gong JG, Gardner JO, Baxter G, Hogg CO, Webb R. Steroidogenesis in bovine granulosa cells: the effect of short-term changes in dietary intake. Reproduction 2002, 123: 371-378.

[110] Simpson RB, Chase CC, Spicer LJ, Vernon RK, Hammond AC, Rae DO. Effect of exogenous insulin on plasma and follicular insulin-like growth factor I, insulin-like growth factor binding protein activity, follicular oestradiol and progesterone, and follicular growth in superovulated Angus and Brahman cows. J Reprod Fertil 1994, 102: 483-492.

[111] Beck U, Stangassinger M, Giesecke D, Meyer J. The testing of insulin receptor activity in ruminants. In: Proceedings of the Vth International Conference on Production Disease in Farm Animals, Uppsala, Sweden, 1983, p 175-178.

[112] Staufenbiel R, Rischk U, Schumacher B, Becker W. Diurnal profile, common and modified glucose tolerance test for studies into insulin and glucose regulation in dairy cows. Dtsch Tierarztl Wochenschr 1992, 99: 69-75.

[113] Nestler JE. Insulin regulation of human ovarian androgens. Hum Reprod 1997, 12, Suppl 1: 53-62.

[114] Nestler JE. Polycystic ovary syndrome: a disorder for the generalist. Fertil Steril 1998, 70: 811-812.

[115] Yen SSC. Polycystic Ovary Syndrome (Hyperandrogenic Chronic Anovulation). In: Reproductive endocrinology: physiology, pathophysiology and clinical management, Saunders, Philadelphia, 1999, p 436-478.

[116] Opsomer G, Wensing T, Laevens H, Coryn $\mathrm{M}$, de Kruif A. Insulin resistance: the link between metabolic disorders and cystic ovarian disease in high yielding dairy cows? Anim Reprod Sci 1999, 56: 211-222.

[117] Barash IA, Cheung CC, Weigle DS, Ren H, Kabigting EB, Kuijper JL, Clifton DK, Steiner RA. Leptin is a metabolic signal to the reproductive system. Endocrinology 1996, 137: 3144-3147.

[118] Amstalden M, Harms PG, Welsh TH Jr, Randel RD, Williams GL. Effects of leptin on gonadotropin-releasing hormone release from hypothalamic-infundibular explants and gonadotropin release from adenohypophyseal primary cell cultures: further evidence that fully nourished cattle are resistant to leptin. Anim Reprod Sci 2005, 85: 41-52.

[119] Williams GL, Amstalden M, Garcia MR, Stanko RL, Nizielski SE, Morrison CD, Keisler DH. Leptin and its role in the central regulation of reproduction in cattle. Domest Anim Endocrin 2002, 23: 339-349.

[120] Spicer LJ. Leptin: a possible metabolic signal affecting reproduction. Domest Anim Endocrin 2001, 21: 251-270.

[121] Huszenicza G, Kulcsar M, Nikolic JA, Schmidt J, Korodi P, Katai L, Dieleman S, 
Ribiczei-Szabo P, Rudas P. Plasma leptin concentration and its interrelation with some blood metabolites, metabolic hormones and the resumption of cyclic ovarian function in postpartum dairy cows supplemented with monensin or inert fat in feed. In: Diskin MG (Ed), Fertility in the high-producing dairy cow, British Society of Animal Science, Edinburgh, United Kingdom, Occasional publications, 2001, 2: 405-409.

[122] Huszenicza G, Haraszti J, Molnar L, Solti L, Fekete S, Ekes K, Yaro AC. Some metabolic characteristics of dairy cows with different post partum ovarian function. J Vet Med A 1988, 35: 506-515.

[123] Mason TM, Goh T, Tchipashvili V, Sandhu H, Gupta N, Lewis GF, Giacca A. Prolonged elevation of plasma free fatty acids desensitizes the insulin secretory response to glucose in vivo in rats. Diabetes 1999, 48: 524-530.

[124] Cnop M, Hannaert JC, Hoorens A, Eizirik DL, Pipeleers DG. Inverse relationship between cytotoxicity of free fatty acids in pancreatic islet cells and cellular triglyceride accumulation. Diabetes 2001, 50: 17711777.

[125] Mu Y-M, Yanase T, Nishi Y, Tanaka A, Saito M, Jin C-H, Mukasa C, Okabe T, Nomura M, Goto K, Nawata H. Saturated FFAs, palmitic acid and stearic acid, induce apoptosis in human granulosa cells. Endocrinology 2001, 142: 3590-3597.

[126] Lu ZH, Mu Y, Wang BA, Li XL, Lu JM, Li JY, Pan CY, Yanase T, Nawata H. Saturated free fatty acids, palmitic acid and stearic acid, induce apoptosis by stimulation of ceramide generation in rat testicular Leydig cell. Biochem Biophys Res Commun 2003, 303: 1002-1007.
[127] Shimabukuro M, Zhou YT, Levi M, Unger RH. Fatty acid-induced $\beta$ cell apoptosis: a link between obesity and diabetes. Proc Natl Acad Sci USA 1998, 95: 2498-2502.

[128] Vanholder T, Leroy JLMR, Van Soom A, Opsomer G, Maes D, Coryn M, de Kruif A. Effect of non-esterified fatty acids on bovine granulosa cell steroidogenesis and proliferation in vitro. Anim Reprod Sci 2005, 87 : 33-44.

[129] Vanholder T, Leroy JLMR, Van Soom A, Maes D, Coryn M, Fiers T, de Kruif A, Opsomer G. Effect of non-esterified fatty acids on bovine theca cell steroidogenesis and proliferation in vitro. Anim Reprod Sci 2005 , in press.

[130] Opsomer G, Grohn YT, Hertl J, Coryn M, Deluyker H, de Kruif A. Risk factors for post partum ovarian dysfunction in high producing dairy cows in Belgium: a field study. Theriogenology 2000, 53: 841-857.

[131] Reist M, Koller A, Busato A, Küpfer U, Blum JW. First ovulation and ketone body status in the early postpartum period of dairy cows. Theriogenology 2000, 54: 685-701.

[132] Andersson L, Gustafsson AH, Emanuelson U. Effect of hyperketonemia and feeding in dairy cows. Theriogenology 1991, 36: 521535 .

[133] Dohoo IR, Martin SW. Subclinical ketosis: prevalence and association with production and disease. Can J Comp Med 1984, 48: 1-5.

[134] Vanholder T, Leroy JLMR, Coryn M, Fiers T, de Kruif A, Opsomer G. Effects of -OHbutyrate on bovine granulosa and theca cell function in vitro. Reprod Domest Anim, in press. 